\title{
PLANNING AND DEVELOPMENT ACTIVITIES IN FUNCTIONAL REGIONS - THE HUNGARIAN CASE
}

\author{
Éva Perger \\ Centre for Economic and Regional Studies, Hungarian Academy of Sciences \\ Rákóczi u. 3. P-O-Box: 261, H-6000 Kecskemét: Hungary \\ perger.eva@gmail.com
}

\begin{abstract}
The paper provides a short overview of the legal and institutional background of functional regions in Hungary, analyses the impact of EU cohesion policy and presents dilemmas concerning the management structures in territorial units crossing administrative borders. The Hungarian case demonstrates that although the need for a place based, territorially sensitive and integrated approach has become one of the most highlighted issues over the last decade, the overall impacts of EU cohesion policy on planning and development activities in functional regions have proved to be controversial. The paper partly relies on the case study of Central Hungary developed in the framework of the ESPON COMPASS project.
\end{abstract}

Keywords: functional regions, EU cohesion policy, regional policy in Hungary, planning and management structures, Budapest Agglomeration, Lake Balaton Resort Area.

\section{Introduction}

The Hungarian case studies, which were developed within the framework of the ESPON COMPASS project, highlighted a general problem of the Hungarian spatial planning and territorial governance system, namely that it cannot really handle functional interrelations crossing administrative borders. It is especially true for the case of the Central Hungary Region. This recognition prompted the author to address the issue of planning and development activities in the functional regions of Hungary. The first result of this work is the case study presented in this paper. Its main goals are to give a short overview of the legal and institutional background, to analyse the impact of EU cohesion policy on planning and development activities in functional regions and to present dilemmas concerning the management structures in territorial units crossing administrative borders. In the interpretation of the study, functional regions are non-administrative territorial units in which settlements are connected by close and reciprocal links, either because of a similar common function (e.g. tourist resort regions, industrial regions) or because of their interdependent functions (e.g. functional urban areas, conurbations). The findings of the paper originate from secondary research, but also supported by the author's earlier researches and practical experiences ${ }^{1}$. The paper also provides two case studies to underline its findings. The description

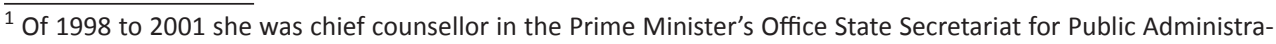


of the Lake Balaton Resort Area case is the result of literature processing and document analysis. The description of the case of the Budapest Agglomeration is based on the case study about Central Hungary that was developed in the framework of the ESPON COMPASS project, and which also relies on semi-structured interviews and a focus group workshop.

\section{Background}

The need for a place based, territorially sensitive and integrated approach has become one of the most highlighted issues in the course of debates and consultations on the EU cohesion policy over the last decade. A number of EU-level policy documents ${ }^{2}$ have also supported the idea of geographically tailored interventions and the creation of a territorially more flexible regulatory and institutional framework for EU cohesion policy.

There were sharp discussions about how to make this idea operational in cohesion policy. In the course of debate on the "Green Paper on Territorial Cohesion" (2008) several countries including Poland and Hungary - emphasised the need to think in terms of functional areas rather than areas within rigid administrative borders. However, the country proposals did not elaborate the nature of governance arrangements that would be required at different levels and within different administrative areas. Moreover, some doubted the will and capacity of the member states and regional, local actors for building up effective planning and management structures for functional regions (Dąbrowski 2013, 2014; Brusis 2014). The consultation on the Fifth Cohesion Report clearly demonstrated that the idea of a more flexible management arrangement to support the targeting of functional areas received limited support either from the European institutions or the member states (Mendez et al. 2011). The official declarations simply underlined the importance of vertical and horizontal cooperation, the multi-level governance approach and the partnership principle. In the end, merely modest operative steps were taken by the EU legislation for the 2014-2020 programming period to provide a new framework for development activities crossing administrative borders. The regulation introduced new optional tools, namely the community-led local development (CLLD) and integrated territorial investment (ITI), to facilitate the delivery of integrated territorial strategies, increased the budget of the European Territorial Cooperation (ETC) and created a new regulation on European Grouping for Territorial Cooperation (EGTC) to promote cross-border cooperation.

The fear, that in the absence of a firm commitment from the EU, territorial cohesion or functional regions cannot be treated systematically (Mendez et al. 2011), seems to be justified. In case of Hungary, the positive effects of the new regulation have not been noticeable. Hungary has not applied the ITI tool and the CLLD tool has been only used in the framework of the Territorial and Settlement Development Operational Programme (TSDOP) ${ }^{3}$ for cultural and community inter-

\footnotetext{
tion and Regional Policy, from 1998 to 1999 the president of the Budapest Agglomeration Development Council and the head of its work organization, coordinating the elaboration of the first Development Concept Of Budapest Agglomeration. From 2000 to 2002 she was the member of the Development Council of Central Hungarian Region. From 2007 she has participated in several research programmes on national management systems of EU cohesion Funds and on regional policy issues. From 2011 she has coordinated projects mainly on rural development and cross-border issues. From 2012 to 2017 she was the member of the Monitoring Committee of the Convergence Regional Operative Programmes and from 2015 she has been the member of the Territorial and Settlement Development Operational Programme Monitoring Committee.

2 Barca Report (2009), Territorial Agenda 2020 (2011), Report on Place-based Approach (2013), Report on the Assessment of Territorial Cohesion and the Territorial Agenda 2020 (2015), Cohesion Reports (2014, 2017, etc.).

${ }^{3}$ The budget of CLLD interventions is merely 147 million euro, $3.7 \%$ of the total TSDOP budget.
} 
ventions in urban neighbourhoods. The geographical location of the country led to a widespread participation in ETC programmes, but even this has had controversial effects on territorial development on national level - as the paper will describe in detail later. Compared to other EU countries, the number of EGTCs in Hungary was very high, but in the summer of 2016 their number declined and their activity decreased significantly. (Svensson \& Ocskay 2016).

In order to maximise the subsidies, Hungary has always adapted to the rules and "expectations" of the EU, but the implementation of the EU cohesion policy has often followed specific national pathways, and mostly characterized by a predominantly formal compliance with EU norms (Perger 2010, 2016; Mezei 2016; Pálné Kovács \& Mezei 2016). Thanks to competent national experts, Hungary has also pursued EU trends in planning activities including key themes, objectives, integrated approach, new instruments, design tools, procedures and appearance of new and often soft and fuzzy spaces of planning (Salamin 2018). This formally displayed positive image, however, can be questioned immediately if we look at the deeper content. This is also the case with regard to the situation of "soft spaces" like functional regions.

\section{Functional regions in the decisions of the Hungarian Parliament}

Functional regions have always enjoyed special attention in Hungary. In 1996, mostly as part of the preparations for the accession to the EU, the Act on Regional Development and Physical Planning (with significant amendments in 1999, 2003, 2004, 2011, 2013, 2016) created an institutional framework for regions that cross the administrative borders of the counties (NUTS 3 level administrative units). The formation of regional development councils was obligatory in "priority regions" (Budapest Agglomeration and Lake Balaton Resort Area at that time) and optional in other regions. According to the original intent, the councils were basically "bottom-up" mixed organizations that provided an institutional framework for cooperation between different development actors (ministries, local governments, chambers, NGOs, etc.). However, the facts that the law defined the possible founders, included provisions for the composition of the members and delegated tasks for "priority region" councils (especially the elaboration of the regional development concept and the contribution to the regional level physical planning) strengthened the top-down character of these organisations. The mandatory members defined by the law were the presidents of the founding county development councils ${ }^{4}$, up to 6 representatives of micro regional associations of municipalities, the representatives of the relevant ministries ( 9 at the time) and 1 representative from each regional economic chamber. In the case of priority regions, the representative of the Government was also a mandatory member. In the nineties, the number of central government delegates and regional actors among the members was about the same. Additionally, the regional development councils could also invite other organizations to the meetings without the right to vote.

The following amendments to the law changed these provisions several times. From 2000 the NUTS2 level regional development councils also became mandatory actors of the regional development institutional system. However, the institutional framework for organizations that did not fit the boundaries of the statistical regions also remained. The NUTS 2 level councils were included

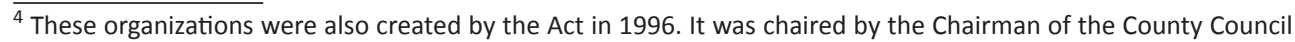
and composed of representatives of the "cities with county rights", the micro regional associations of municipalities, the responsible minister, the territorial economic chambers and employee and employer sides of the County Labour Council.
} 
into the potential founders of these "special regional councils" 5 and their delegates also became full members. At the request of the council or on their own initiative, different ministers could also delegate their representatives. The "special regional councils" could invite other organizations and persons to participate in their work, but their number could not exceed one third of the mandatory members. After the amendment of 2000 , the Balaton Region remained the only priority region. In case of the Balaton Development Council, the inclusion of the representative of the Government and the delegates of 10 ministers was also mandatory. The number of representatives of central organisations, who was involuntarily or voluntarily involved in the council's work, steadily increased. 2004 brought the reversal of this trend: the possible number of representatives of micro-regional development councils decreased to 3 , full representation of chambers disappeared and the obligation of the Balaton Development Council to involve delegates of the different ministers was lifted. However, from 2006 till 2011 the representatives of the National Development Agency (NDA) and the managing authorities (different departments of the NDA) also became full members of the Balaton Development Council at the Council's own discretion. In 2004 the law required the Central Hungary Regional Development Council and the Municipality of Budapest to re-establish the Budapest Agglomeration Council. In addition to the Mayor of Budapest and the head of the regional development council, the representative of the Government and 3 representatives of Budapest districts and the micro-regions of Pest County also became mandatory members.

After the transformation of the administrative and territorial development system in 2011, the county governments have become the main actors in regional development. The county development councils, the NUTS 2 level regional councils and the Budapest Agglomeration Development Council have ceased to exist, so the legitimate circle of founders of a "special regional council" has narrowed to the county assemblies. The number of the members of the regional development councils has reduced and only the county presidents and one representative from each county assembly became full members. The representation of the municipalities has virtually disappeared. Furthermore, territorial representatives of the Chamber of Commerce, the Head of the County Government Office, the State Chief Architect have to be and other business organizations, non-governmental organizations may be invited to attend the meetings. From 2011 to 2013 the representative of the Government, from 2014 the representative of the minister in charge of strategic planning of territorial development and representatives of the ministers responsible for implementing EU funded operational programmes also became mandatory members of the Balaton Development Council. The council of the new priority region established in 2014, the Tokaj Wine Region Development Council is very special one since its operation covers only part of a county. Consequently, it has a specific membership composition. In addition to the county president and the delegate of the county assembly, the Chairman of the Tokaj Wine Region Council, the Chairman of the Supervisory Board of a state owned wine wholesaler and importer company (Grand Tokaj Zrt), and a representative of the minister in charge of general policy coordination are the full members.

According to the law, the operating costs of the "special regional councils" have always been covered by members' contributions or by means of tenders. Only the development councils of priority regions could receive central budget support. Without other resources, separate work organizations or development agencies could not operate in these special regions, with the exception of the priority regions. Although between 1999 and 2013 the special regional development councils could make arrangements with local actors to finance their regional programmes and devel-

5 Since the "region" term is interpreted in Hungary as NUTS2 region, hereinafter we use "special" flag for these "grass-roots" regional councils. 
opments, nevertheless in the absence of local resources and management capacities we can hardly find such examples. Central resources for "functional region level" development programmes or projects have been only available to Balaton Development Council on the basis of direct governmental decisions.

Until 2011 a total of eight "special" regional development councils were created (in the Budapest Agglomeration and Balaton Region on mandatory and in the other six regions on voluntary basis). The personnel capacities and assets available to the councils, and in this context, the level of performance of their tasks showed great differences. Presently there are total of 9 Regional Development Councils (Fig. 1). 2 of them are "obligatory" (Balaton and Tokaj) and 7 are organized on voluntary basis. 5 of the councils operate in tourist regions, 1 operates in the "Homokhátság" (Sand Dunes between the Danube and Tisza), in a typically rural region which is particularly vulnerable to climate change, while the obligatory Tokaj Development Council operates in a wine region. 2 of the councils have been organized for the cooperation of settlements along existing or planned motorways. These councils are rather lobby-organizations to construct the motorway. Unfortunately, there is very little information available about current activities of the regional councils, apart from the Balaton and the Tokaj Development Council, which carry out mandatory tasks and receive central budget support.

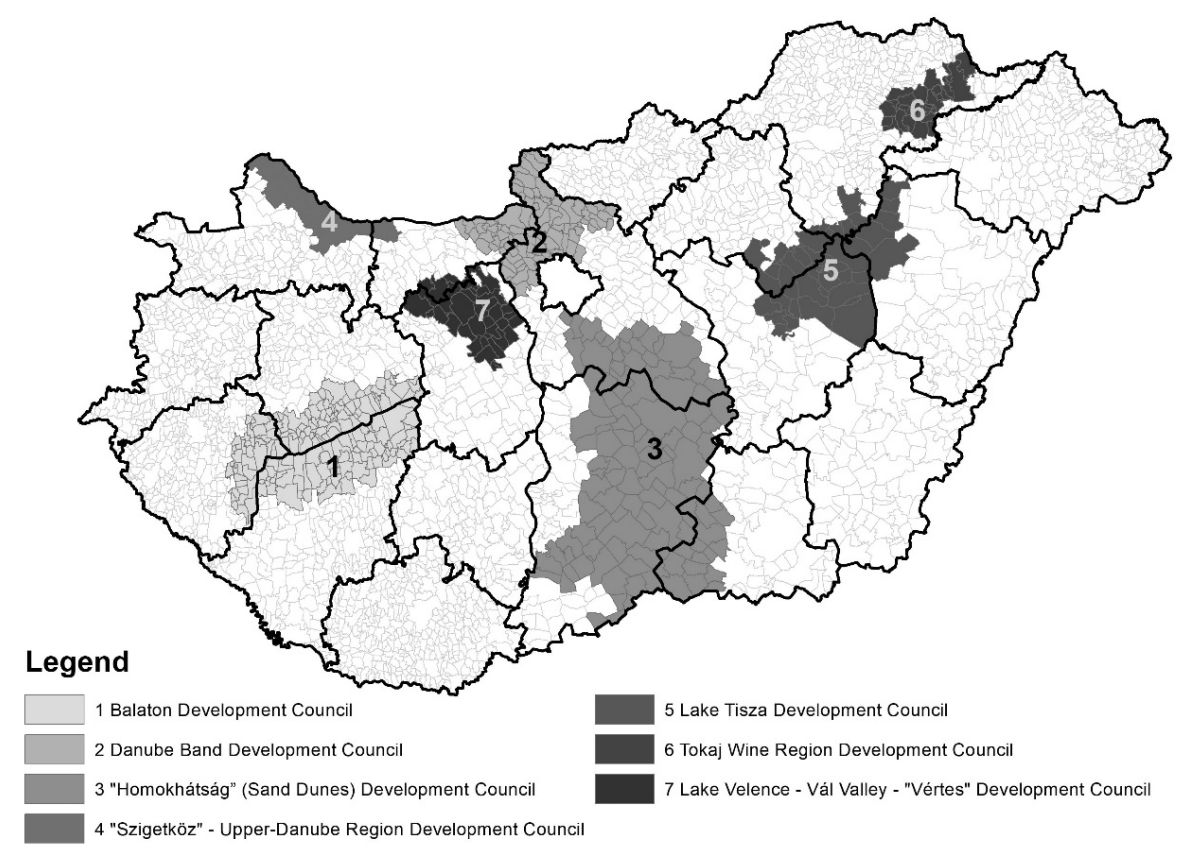

Figure 1. Regional Development Councils in Hungary

Source: own design based on organisational and operational regulations of the councils.

National spatial development concepts adopted by Parliament decrees have also paid special attention to functional regions. The first National Spatial Development Concept (NSDC) in 1998 set up long-term development goals and priorities for some identified target regions like "backward regions", "regions of industrial crisis", "rural areas", "border areas", and "environmentally vulnerable areas". The concept also highlighted the group of cities which operated as functional centres. 
In the second NSDC adopted in 2005, there was a small shift in the spatial development objectives, as the competitiveness of the regions had become the first priority. Reflecting the changed logic, in the chapter summarizing the medium-term territorial goals, the "Metropolitan Region of Budapest" and the regional development poles (urban regions of regional centres like Pécs, Miskolc, Szeged, Debrecen etc.) got into the first line of priority areas. The category of "backward regions, external and internal peripheries" was still highlighted. In addition, a new category of the so-called "integrated areas of national significance" emerged, namely the "Lake Balaton Region", the "Tisza Region" and the "Areas bordering the Danube" (Fig. 2). Furthermore, the distinct spatial categories of "border regions" and "rural areas" were also defined. In this latter category "areas that rich in natural and cultural landscape values", "areas of scattered farmsteads", the "Homokhátság", "areas with small villages", "areas inhabited by national minorities" and "regions with high proportions of Roma population" were differentiated.

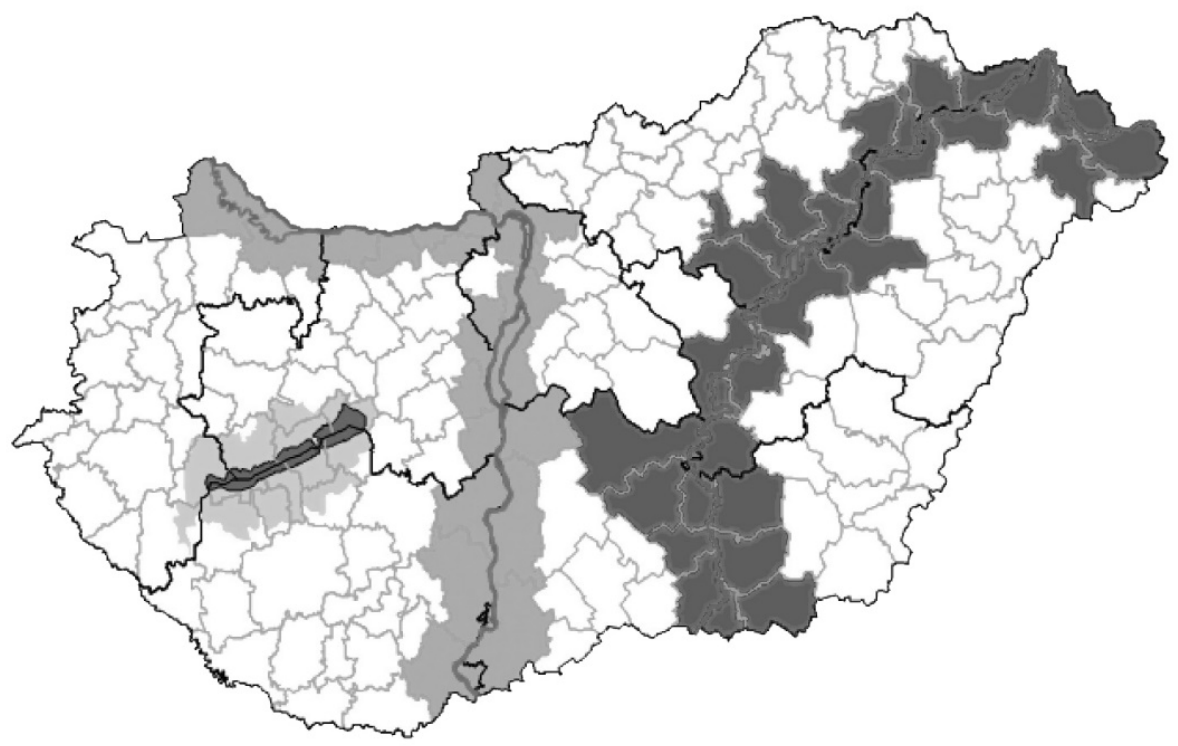

Figure 2. Integrated Development Areas of National importance in NSDP 2005 Source: National Spatial Development Concept (2005).

The National Development and Territorial Development Concept (NDTC), which was adopted in 2014 , has acknowledged that "the difficulties so far experienced in Hungary's territorially based developments stemmed from the fact that those developments have failed to intervene in the actual spatial organisation processes. The practice has so far mostly been aimed at developing territorial units organised along administrative lines, which often did not really reflect the real spatial connections; these units were not characterised by cooperation between communities, by the identification of mutual benefits and compromises, or by a city's responsibility for its territory" (NDTC 2014: 122). Consequently, the document dealt with functional areas at several points, and generally emphasized the role of "functional urban regions" in regional planning and development but without any concrete proposal. This concept also referred to specific functional areas but has classified them by national policy goals and directions. The result was a rather long list and an inconsistent structure of different categories of regions, or particular priority regions. Finally, a total of 20 categories were mentioned, including almost all of the regions which had been somehow included 
in the previous concepts. Other regions were highlighted in an official concept for the first time (e.g. very small territorial units such as the "Cserehát" and the "Ormánság", the so called "special economic zones", and - as a reaction to new challenges - "areas most affected by climate change").

After the review of the development concepts, we can conclude that the number of identified special region types and delimited regions has increased continuously, dividing them into more and more subcategories, displaying more and more specific areas. As the figures of the highlighted regions in the different regional development concepts illustrate, it is difficult to keep track of the changes because it was almost accidental which areas has been selected and why the content and the way of delimitation has changed. ${ }^{6}$

\section{Functional regions in decisions of the central government}

The main purpose of the designated representation of the different types of regions or particular functional regions in national spatial development concepts is to define territorially differentiated, specific development goals and interventions (more precisely "recommendations") for the regional actors. However, in the absence of adequate local resources and tools, the key development actors throughout the entire period have been the central government and the different ministries. The decisions of these bodies have only in exceptional cases applied the spatial categories appearing in the national development concept "in force". The decision-makers have often defined the targeted area based on current sectoral policy goals or on direct political objectives. These decisions on a specific region afterwards have often been inserted in the national spatial development concept approved by the Parliament.

Another typical aim of the nomination of specific areas by Parliament decisions is to ensure a coordinated and integrated development of functional areas that do not fit into the public administration system. However, the attempts of the Government to fulfil this goal have been unsuccessful up to this point. The preparation of the complex regional programmes of the New Hungarian Development Plan (the basis of the Common Strategic Framework for the 2007-2013 planning period) for example clearly relied on the NSDC adopted in 2005. The so called priority programmes included the Danube Complex Programme, the Tisza Complex Programme, the Balaton Complex Programme and the "Poles Programme", which promoted the development of the regional centres. The sustainable development of the "Homokhátság" also appeared as a priority project. Designing and implementing of these programmes would have required their elements to be incorporated into sector-type operational programmes. Sectoral ministries, however, resisted against the use "their" resources following territorial logic and the Government also failed to find the optimal organizational form for the management of these complex programmes. As a result, these programmes virtually disappeared in the process of preparing for implementation.

Another common purpose of highlighting a special region in a national concept is to create a background for decisions on funding development programmes, or projects. In the first half of the nineties, in addition to a settlement-level support system, the Government supported individual counties (7 from the existing 19 counties), a large region (Great Hungarian Plain) and some smaller areas of industrial crisis (e.g. Ózd, Komló, Záhony region) with specific interventions. The regulation of the so called "business zones" in 1996 was fit to the sectoral logic. Since 1998, the allocation system of spatial development resources has provided support to backward regions

\footnotetext{
${ }^{6}$ In some cases, the delimitation of the areas was based on settlement-level, in other cases relied on micro-regional (LAU 1) data, and sometimes there was a lack of explicit demarcation.
} 
identified in the NSDC, which is the only system that, albeit in varying form and content has existed continuously, granting certain benefits in a normative manner to disadvantaged micro-regions (now districts). However, the allocation of funds on the basis of direct government decisions has not ceased either. Different counties, and certain special areas (e.g. "Homokhátság", "Balaton Region", "Tisza Valley", Cserehát Microregion) remained as target areas. The focus and support of the latter's developments has often "slipped" into sectoral competences (such as the water management sector or the social sector) in practice. From the middle of the 2000s, in parallel with the increasing weight of EU subsidies, domestic resources became limited and the scope of $\mathrm{ad}$ hoc government decisions on specific areas also decreased. After 2010, resource allocation based on ad hoc direct Government decisions gained significance once again, this time assigning EU funds of different operational programmes to particular functional regions. However, these decisions did not consistently follow the priority areas in the actual NSDC or NDTC (such as the Ancient-Drava Programme ${ }^{7}$, Tokaj Wine Region). The development of the "Balaton Region", the "Tisza Valley" and the "Homokhátság" was primarily treated as sectoral, namely water policy issue.

The 2014-2020 Partnership Agreement stated that "the management of territorial problems and potentials of national importance exceeds the resources of regional actors and regionally decentralized developments and will therefore be primarily addressed by sectoral operational programmes in the 2014-2020 period"(p. 222). The document mentioned particular regions with an indicative basis where the Government has been planning national regional development initiatives, namely the "disadvantaged areas", "the metropolitan economic growth zones" and the "Lake Balaton Region". Since most of the operational programmes (OPs) have essentially non-territorial character, and the Territorial and Settlement Development OP only provides resources for small investments within county or city boundaries, only ad hoc Government decisions remained as a chance for integrated development of a functional region. In everyday practice the already mentioned "Balaton Region", "Ancient-Dráva Region" and "Tokaj Wine Region" have received special governmental attention and indicative development resources, but new spatial focus programmes such as the "KRAFT (Creative City - Sustainable Region) Programme" for the town Kőszeg and its surroundings or the "Mura National Programme" has also been approved. Furthermore there have been Government decisions on several so called "priority tourist regions" ${ }^{\prime \prime}$, as a territorial aspect of a sectoral programme.

The Government's report for the Parliament on the territorial processes in 2012 provided a good overview about the effectiveness of highlighting functional regions in spatial development concepts. It stated that the objectives of the spatial development policy were not fulfilled and analysed the development failures of the highlighted regions in detail. The NDTC text in 2014 also referred to these failures setting out that "the special region types and their respective targets defined in the NSDC were, for the most, not conspicuous in the sectoral policies and/or were practically not integrated into domestic development policy. Little spatial concentration and few special interventions tailored to specific areas were realised" (NDTC 2014: 12). The Parliamentary Report about territorial trends in Hungary in 2016 can be considered as a kind of revision of the existing NDTC structure of the spatial categories, as it did not strictly follow the NDTC system when presenting the intervention areas of the spatial development policy. It listed the following regions: "Budapest and its region - Central-Hungarian region"; "Towns and their regions" (including indus-

\footnotetext{
7 The territory of the "Ancient Dráva Programme" partly covers the territory of the "Ormánság", which is a highlighted microregion in the NDTC.

${ }^{8}$ Priority tourist regions are regulated by governmental decisions. They are: Balaton, Sopron-Fertő, Tokaj, FelsőTisza and Nyírség, Dunakanyar, Debrecen-Hajduszoboszló and Hortobágy-Tisza Lake regions and other decisions are expected on Gyula-Békéscsaba, Velence-Etyek, Muraföld, Pécs-Villány Mohács regions.
} 
trial crisis areas); "Rural areas" (including areas of scattered farmsteads, areas of small villages, and one specific micro region, the "Ormánság"); "Priority regions for territorial development" (Balaton and Tokaj Region); "Regions of economic and social convergence" (beneficiary districts, sometimes including areas of high Roma population and free-trade zones); "Border regions" (cross-border districts); "Areas most affected by climate change" (especially the "Homokhátság"). The summaries about the development of intervention areas reported very modest progress and in some cases - even the accumulation of the problems.

\section{Planning and development practice in functional regions}

Being a local governmental competence, land-use planning usually does not extend beyond administrative borders. Although the national level physical plan and the county level plans (structural plan and zoning plan) determine the framework for settlement level plans and the regulation lays down a number of conciliation obligations, the fragmented administrative structure leads to a fragmented land-use planning regulation in the everyday practice. The priority regions can be considered an exception: in their case, the local level land use and regulatory plans are more strictly regulated by the Parliament. (Act on Spatial Planning in the Agglomeration of Budapest 2005, revised in 2011; Act on Balaton Special Resort Area Spatial Planning Plan and Balaton Spatial Planning Regulations 2000, revised in 2008). The preparation of these acts was the task of the minister responsible for spatial development, in consultation with the regional development councils, the affected counties and - in case of Budapest Agglomeration - with the capital. Although the Budapest Agglomeration is no longer a priority region according to the Act on Regional Development and Physical Planning, the amendments to the two above mentioned acts are currently on the agenda. Undoubtedly, the Development Council of the Budapest Agglomeration could not be involved in this process as it has ceased to exist in 2011.

Strategic planning in institutionalized functional regions is widespread and usually involves a wide range of local actors. The main purpose of the planning activity is to harmonize the regional actors' conceptions, but the ultimate goal is mainly to secure the acquisition of funds for investments in the given area, i.e. to influence EU planning documents and ad hoc government decisions. Since the frequent changes of the nationwide strategy, regulation and central governmental decisions often change the framework for planning, the plans have to be reworked over and over again. Due to the lack of competencies and resources on local and functional region level, the strategic plans are often remained unutilised. Preparation of development concepts and programmes in priority regions determined by the law is the duty of the regional development councils, but must be approved by the Government. However, these plans have rarely been placed on the Government's agenda (so far the only exception is the Development Concept and Strategic Programme of the Lake Balaton Region in 2015). On the other hand, the Government has approved the development concept or programme of several other regions that have not been highlighted as a priority area in the NSDC or in the Act (Development Concept of the "Lake Velence and Vértes Priority Recreational Area" in 2003, development programme for the same region - in 2005, the National Development Programme of the "Tisza-Lake Region" in 2013, the National Development Programme of "Tokaj-Hegyalja Wine Region" in 2013) ${ }^{9}$. These decisions have been probably due to the pressure of the political lobby of the regional actors.

\footnotetext{
${ }^{9}$ Tokaj Region is a "priority region" by the Act since 2014 but wasn't highlighted in the NDTC, which was approved in the same year. This example perfectly illustrates the inconsistency and ad hoc character of the Hungarian spatial development policy.
} 


\section{The impact of EU cohesion policy on planning and development in Hungarian functional regions}

Hungary is one of the countries in which the share of EU subsidies in public development expenditures is very high. In the $2007-2013$ planning period nearly $50 \%$ of public sector investment expenditure was granted by EU funds and this ratio reached $6-8 \%$ in the private sector as well (Boldizsár et al. 2016). Due to the fact that the absorption of EU subsidies has become one of the most important political ambitions, EU cohesion policy has had a significant impact on regional planning and territorial governance. The most robust influence of cohesion policy on national structures could be observed in the preparation period when Hungary tried to build up an institutional and planning framework suitable for the absorption of EU funds. This period was full of expectations concerning decentralization and the involvement of regional and local actors. Grassroots organizations were developed for the coordination of development and planning activities both on microregional and regional levels, which process was also supported by EU funds (PHARE Programme). New regional policy institutions based on the principle of partnership emerged (self-government associations, development councils and agencies on different territorial levels). As it was mentioned above, the Act on Regional Development and Physical Planning also placed emphasis on regions that crossed strict administrative borders.

While in the 1990s there was a strong political pressure on the member states to build up regional institutions, at the beginning of this century a shift happened. Due to the overall European problems like competitiveness, employment, environment, common currency, nationalities, etc., the scope of the regional policy was subordinated to the overall European effectiveness and efficiency. The pressure for decentralization ceased and the Commission started to favour concentrated and centralized management structures in the new comer CEE countries. Although the preparation phase initiated obvious decentralization tendencies, the utilization of EU structural funds - due to the EU Commission pressure assisted by the national governments - resulted in a temporary or persistent recentralization process nearly in all countries. In Hungary practically two parallel structures were created, one for developments financed by domestic sources and one for the EU cohesion funds. In the period of 2004-2006, the practice of domestic regional development became slightly decentralised, yet the newly established system for the management of EU funds followed a centralized bureaucratic model and special proceedings. The allocation of EU funds was mostly based on sectoral logic. The urge for creating bottom up institutions based on local partnerships diminished.

This situation has deteriorated further in the later planning periods. Domestic subsidies have reduced to a minimum level. The long lasting political debates have hampered strengthening secondary level local governments and the central governments have enforced their intention for a strong centralization. Under the circumstances of the increasing national scope of authority after 2006, Hungary was not necessarily prepared for multi-level and geographically flexible territorial governance. The country was characterized by strong traditions of centralized governmental systems, poor cooperation culture and weak regional and civil actors. Unfortunately, despite the preceding expectations, the EU cohesion policy has not contributed significantly to the decentralization process, the strengthening of regional actors, or the development of cooperation mechanisms. Although the principles of subsidiarity and partnership has been increasingly emphasised, the Commission created incentives for the national governments to focus on meeting with formal procedural obligations and ensuring timely absorption. The principle of shared management granted a relatively large freedom for the member state governments in designing 
the territorial framework and institutional system of the implementation. And just like in the past, the Hungarian governments decided to follow a centralized bureaucratic model once again (Perger 2010, 2016; Mezei 2013). The resource-oriented, EU conform planning activity conducted by the central government got priority and the "traditional" types of territorial plans initially defined by the Act on Regional Development and Physical Planning (spatial development concepts and programmes at different territorial levels) withered. The regional institutions involved in the planning and implementation process were not given democratic authority and autonomy and have always operated under strict governmental control. In reality, meaningful representation of territorial interests and territorial identity has been absent from the Hungarian practice (Mezei 2016). The main coordination mechanism has always had a political character and the fulfilment of the principle of partnership has been formal and mostly initiated from above (Perger 2010, 2016). Although functional regions have enjoyed special attention in national territorial planning documents, they have rarely appeared in the EU planning documents. Planning experts have continued to keep the issue of functional regions on the agenda, but political decisions often did not take this approach into consideration. The missing local resources, competencies and management structures remained the main challenges for the complex development of functional regions.

With the strong and general centralization process is undergoing in Hungary since 2010, the country is getting further and further away from the multi-level governance model. The decision-making role of the central government authority has become much stronger and the decline of local governments' role can be described as dramatic (Ladner et al. 2016). In this situation the local/territorial self-governments have tended to focus more on their own projects within their own administrative borders, instead of a wider area-based approach. Changes in EU cohesion policy have also strengthened the centralization trends. The thematic orientation and the strict performance review has affirmed centralized models of implementation since the member-state governments would hardly take the risk to delegate their responsibilities to the regions or other territorial bodies. In the absence of a multi-level governance model there is little hope for successful soft planning practices in functional spaces and even less so that programmes and projects crossing administrative borders can be realized. Practically the only chance for integrated development in a functional region is a development programme and/or specially assigned resources approved by the central government. Therefore, the regional development councils and other bottom-up organizations crossing county borders are mostly characterized as "rent seekers".

In addition to enabling a highly centralized planning and management structure of EU funds, other features of EU cohesion policy regulation have also had controversial effects in Hungary.

First of all, the typical project based selection system for allocation of EU funds is disadvantageous for managing integrated territorial programmes. The case studies of the latest researches pointed out that in most cases, an ad hoc development policy exists on local level in Hungary (Perger et al. 2014; Perger 2016). The competition for winning the tenders has weakened the local actors' propensity towards cooperation. The project-based planning and implementation practice and the bureaucratic procedures often work against local creativity and innovation. The projects rarely followed a clear regional concept and were implemented in a disorganized manner creating "development islands".

Secondly the territorial framework for planning and implementation of cohesion policy has been mainly aligned with administrative borders. The NUTS 2 region based approach of the 20072013 development period laid out a framework that the domestic designers and policy makers did not want to overstep in Hungary. The cases of the Budapest Agglomeration and the Balaton Region, which will be described below, illustrate this controversial effect very well. There have been numer- 
ous attempts to develop and implement integrated development programmes in other functional regions as well but they failed partly because of the fact that the territory of the functional regions belonged to different NUTS 2 regions (and to different NUTS 3 level administrative counties) which did not want to concentrate their allocated resources to a functional region partly outside of their borders. In some cases, the differences in the regional aid map have also led to contradictions.

In author's view, neither the cross-border programmes nor the European macro-regional strategies have had a clear positive impact on the development of functional regions, since there is an inconsistency between the perception of the target region in the national and EU-wide policy. The target areas of EU cross-border programmes are identified at NUTS 3 level. Since Hungary is a relatively small country with many neighbours, merely 3 of the 19 counties of Hungary are considered non cross-border areas. This classification works against the concentration of resources in the real cross-border functional regions and the most depressed peripheral areas, which cover a much smaller territory along the borders. In the case of Strategy for the Danube Region the target area is the whole country. As a consequence, the NDTC approved in 2014 did not distinguish the territory along Danube-riverside from the Danube Region and the projects contributing to the implementation of the Danube Strategy do not necessarily support the integrated development of the Danube riverside.

The same contradiction exists in the case of rural regions. In order to maximize subsidies, the Rural Development Programme covers the entire territory of the country, while LEADER is an intervention for settlements with less than 10000 inhabitants and outskirts of towns with more than 10000 inhabitants, if the proportion of the outskirts population exceeds $2 \%$ (the settlements in the agglomeration of Budapest are exceptions). The settlement-level definition per se would allow co-operation between rural settlements in different counties, but the new national regulations prohibit the crossing of county boundaries. In the NDTC, districts (administrative units on LAU 1 level) below the population density of 120 per $\mathrm{km}^{2}$ are considered as rural regions. To determine more precise territorial goals for the very different rural areas rural subcategories were created in the concept, but special development tools for these categories have not been elaborated. The only exceptions are the "areas of scattered farmsteads", which were addressed by a separate parliamentary resolution and a nationally funded programme in the rural development strategy. For the implementation of this programme the budget laws have provided moderate domestic resources since 2011, allocated to the Ministry of Agriculture, i.e. under sectoral supervision.

Thirdly if we look at the rules and programming structure of structural funds, we also can find elements that have hindered implementation of programmes in "functional regions". Territorial cohesion got less attention than economic and social cohesion either on EU or on national level. Consequently, the allocation of EU funds in Hungary has mostly been based on sectoral operational programmes. The regional (or territorial) OPs have played only complementary role and the functional territorial interconnections were not taken into account. The dissension of the towns and its surroundings has been further reinforced by the duality of regional development and rural development programmes. In the current period NUTS 2 level regional OPs were not even developed in Hungary, only a single Territorial and Settlement Development Operational Programme. The programme applies a specialized territorial selection system based on the Integrated Territorial Programmes of the counties and the cities having county rights. However, the programmes of the counties and the cities was prepared in the framework of resources allocated by a Government Decree, according to a central template and output indicators defined by the ministry, and under strict government supervision. The system starkly separated the counties from each other and the county seats from their surroundings by setting up special priority axes for the counties and for cities having county rights. 
Consequently, the Integrated Territorial Programmes does not support (sometimes even hinder) planning and development activities crossing administrative borders.

\section{The case of Budapest agglomeration}

The delineation of a functional region including Budapest and its surroundings is not an easy task, because it depends on what aspects we take into consideration. It is obvious that a suburban zone formed around Budapest, which is in many aspects strongly connected to the city. However, the functional urban region of Budapest stretches far outside the suburban ring and includes more loosely associated settlements too (Fig. 3). In case of the most strongly interconnected area of Budapest Agglomeration coordinated planning and development is essential. Without partnership, coordination and joint planning the process of urban sprawl, that has become one of the most significant phenomena characterizing the development of the region in the past 25 years, leads to transport, environmental, economic and financial conflicts. However, the coordination in this region is very difficult, as the administrative structure is extremely fragmented. The territory of the Budapest Agglomeration includes the City of Budapest and a part of Pest County, which are both second-tier administrative units governed by local governments. The capital has a special status with both municipal and county functions and has a peculiar dual self-government system. This means that in addition to the Municipality of Budapest, each of the twenty-three districts have their own local governments, with elected mayors and a body of representatives. The General Assembly of Budapest and the district bodies of the representatives are equal in terms of their basic rights, with no hierarchic relationship between them. According to the current delineation, 80 of the 187 settlements of Pest County belong to the Budapest agglomeration, although according to several experts, this area is bigger today. Despite their interconnectedness, each of them has full municipal authority.

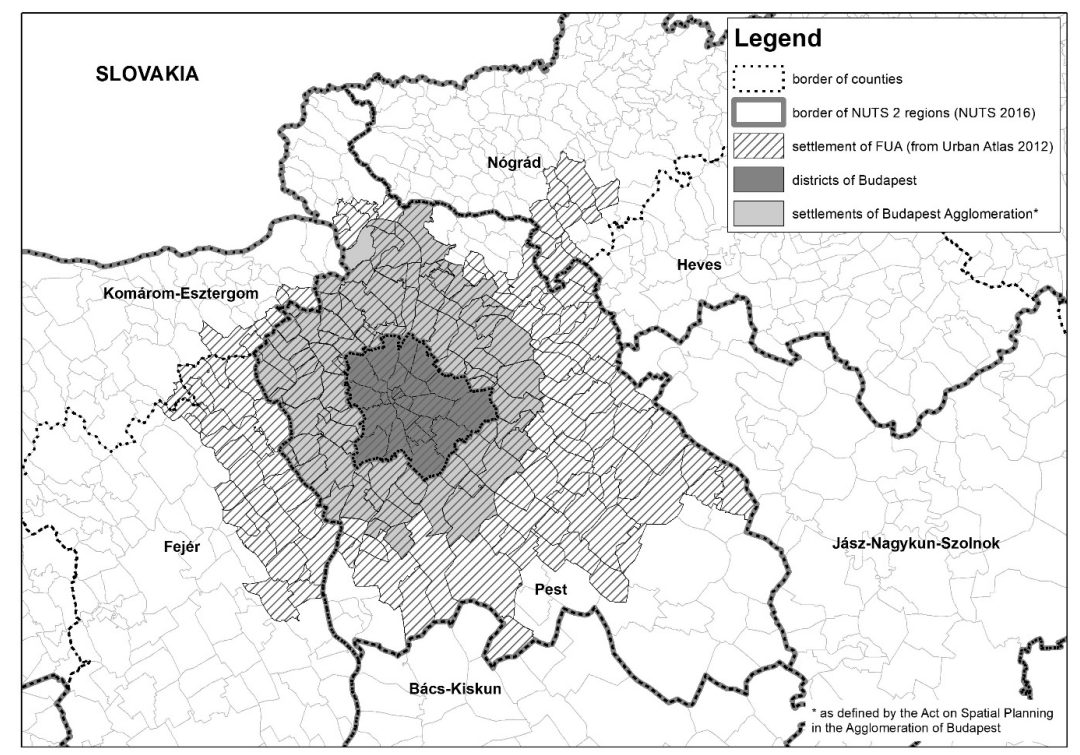

Figure 3. The Region of Budapest Source: own design. 
The coordination on spatial planning in the Budapest Agglomeration dates back to the late 1980s. As for strategic planning, the first development concept and the first development programme of the Budapest Agglomeration were developed in 1999 for the territory defined in 1997 by a Government Decree. These documents were worked out in close cooperation with the different stakeholders of the suburban region, and were coordinated and finally approved by the Budapest Agglomeration Development Council. However, these documents have never been on the agenda of the central government. The creation of the land-use plan for the suburban region adopted by the Hungarian Parliament in 2005 was also based on a region-wide consultation process with the affected local governments. Despite all the differences and debates between Budapest and Pest County, their experts were able to successfully cooperate in their spatial planning efforts. Consequently, planning documents on different levels (Budapest agglomeration, Pest county and Budapest city) have often set common goals, including promoting polycentric and more balanced territorial development in the suburban region.

In December 1999, in parallel with the creation of the Regional Development Council of the Central Hungary Region the amendment of the Act on Regional Development and Physical Planning disbanded the Budapest Agglomeration Development Council. With this decision, the only institution which provided a framework for reconciliation and joint planning for the actors (central government, city government, Pest-county government, municipalities, chambers, civil actors etc.) in the closely interrelated agglomeration area was ceased to exist. In administrative terms Central Hungary Region consisted of two NUTS 3 regions, the City of Budapest (1.8 million inhabitants) and Pest County (1.2 million inhabitants). The region was characterized by significant regional disparities between Budapest and Pest County. There were also major differences between two parts of Pest County. Nearly two-third of the county's population lived and nearly $80 \%$ were employed in the Budapest suburban zone. This "belt" could be characterized by similar social indicators as the city of Budapest. The "rest" of Pest County was less developed. Some territories of the county could even be considered as lagging areas.

The territorial framework for cohesion policy was quite different from the spaces drawn by real territorial connections and neither of them followed the territorial framework of the spatial planning system in Budapest Region. Due to its relative high GDP per capita value, the Central Hungarian Region was subject to objective 2 "Regional competitiveness and employment" in the 2007-2013 planning period, while until 2006 it belonged to objective 1, "phasing in" regions. The ERDF funding available for the region was planned and realised within a single operational programme, which included both sectoral and regional priorities. This situation gave even more chance for the bodies of the central government to determine the content and the implementation of the regional OP. Moreover, several so called priority projects based on governmental decisions were carried out in the region which were not always fully aligned with urban plans but directly influenced the development trends of the city. During the planning and implementation process of the Central Hungary Operational Programme, only mandatory formal consultations took place with the regional actors. Although the regional development agency was involved in the development of the programme and fulfilled tasks of the intermediate body in relation to some priorities, it clearly operated under strict central control. The programme itself did not really handle the problems occurring at the agglomeration level. Although the Budapest Agglomeration Development Council was re-established in 2006, it did not receive real competencies or resources. This council also worked out a middle term concept and programme in 2006, but these documents have never come into force. 
Being an objective 2 region, the available subsidies per capita were minimised for the programming period of 2014-2020. As the preparation for the new planning period Pest County and Budapest have worked out their planning documents (development concepts and programmes). Budapest and the towns in Pest County also prepared their integrated urban development strategy. However, the planning process of the Competitive Central-Hungary Operational Programme clearly fell into central governmental competence and the implementation was the task of the managing authority operating in the Ministry of National Economy (at present Ministry of Finance). Since the structure of the programme is based on thematic priorities, territorial issues are not reflected significantly. Although the existing development planning documents were worked out within the administrative borders, Budapest City Government have involved the Pest County Government in the preparation of its four thematic development programmes, which are strategic documents with an entirely new perspective aiming to harmonise the development projects with respect to their subjects - such as development of Danube riverside, development of brownfield areas, social urban regeneration and promotion economic development and job creation in Budapest. However, the implementation of these programmes is hampered by the lack of resources and institutional background.

In December 2015, at the initiative of Pest County, the central government decided to split the statistical NUTS 2 region of Central Hungary into two separate NUTS 2 units (the more developed Budapest and the less developed Pest County) and initiated the process of separation. The decision was supported by both the Pest County Council and the Budapest Municipal Assembly. The EU Commission approved the request, so from 2018 Budapest and Pest County was separated by both county and NUTS 2 statistical region border. The separation was clearly the result of EU cohesion policy regulation. While the possibility of using EU funds for both mid-level administrative units might be beneficial, the coordinated development of the agglomeration area was further hampered. The even sharper borders between the capital and its surroundings would reduce the chance to counter the negative effects of the uncontrolled suburbanization.

\section{The case of Balaton region}

Balaton Region as an organically interconnected tourist region has also been a priority area for a long time. The territory of the "Lake Balaton Resort Area" (Fig. 4), according to the current demarcation, covers 180 settlements around the Lake Balaton that in administrative terms belong to three counties (Somogy, Veszprém, Zala). Due to the interrelations between them as well as their similar opportunities and problems, these settlements are more connected with each other than with their respective county seats. Local social and political movements already showed a close internal connection in the region decades ago, although often with the motivation of pursuing common interests rather than to create real partnership networks. The first development council type institution was established in the Lake Balaton Region in 1993, before the law on territorial development. Moreover, it was the first "regional" type development institution that crossed the county boundaries. Its operation was primarily based on the will of the local governments to cooperate, although the establishment of the council was eventually formalised with a government decision. The Ministry of Regional Development provided support to this purpose with the intention of introducing this new type of institution in the Hungarian regional development system. However, this also turned out to be the main obstacle to the council's operation, because neither the legislative framework nor the practical techniques of financing or mechanisms of co-ordination with other actors had been developed yet. 
In 1999, following the provisions of the 1996 Act, the council was re-established. From 1999 to 2004 the development of the Lake Balaton Region was financed from domestic central government sources. After 2004 support of the region from domestic sources did not cease, but its volume decreased significantly. In the National Development Plan for the 2004-2006 programming period priority regions were not mentioned. As a result, developments in the area of Balaton Region had to be implemented from the sources of sectoral operational programmes and the single Regional Operational Programme. In comparison with the funding arrangements of the previous period, this marked a very unsuccessful period for the region. It received less development resources than any other development region or county in Hungary. (Kabai 2012, 2016)

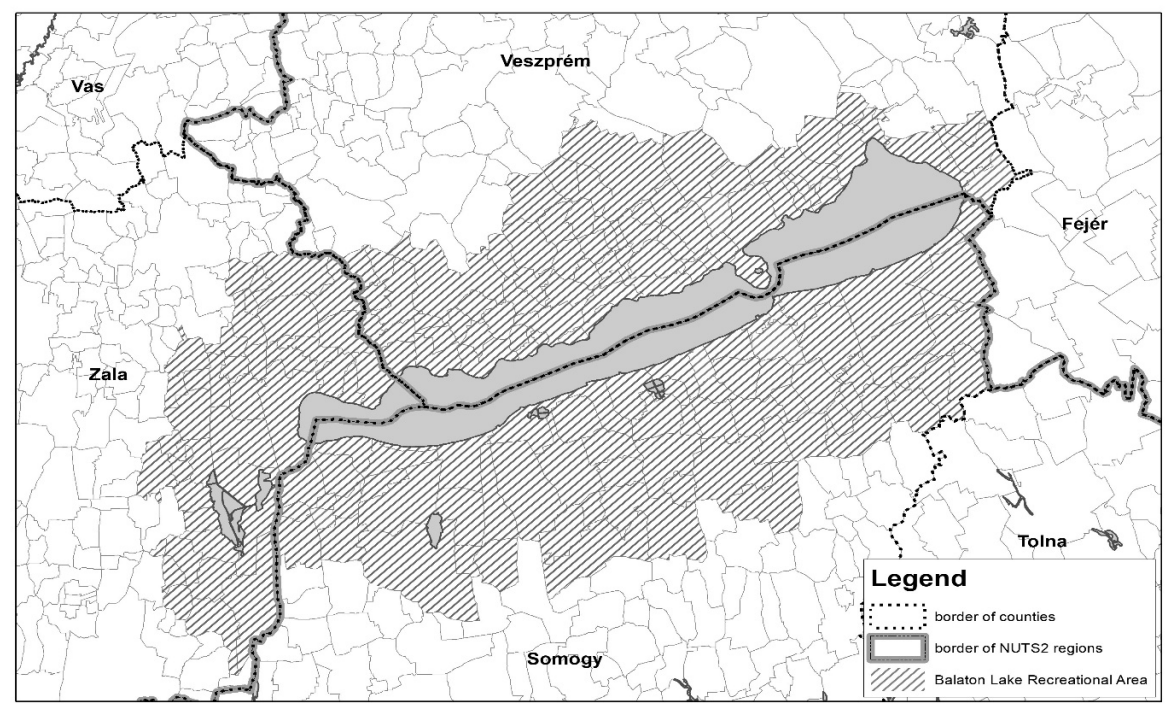

Figure 4. Lake Balaton Resort Area Source: own design.

From 2000 onwards, with the establishment of NUTS 2 level regional development councils, the settlements of the Balaton Region belonged to three different NUTS 2 regions. (Central, Western and Southern Transdanubia). During the preparation of the 2007-2013 planning period, regional operational programmes were worked out for all the 7 Hungarian NUTS 2 regions. However, in order to address the financing needs of the harmonized development of the Balaton Region, the first versions of the national level planning documents also included a separate Balaton Programme. Therefore, the Balaton Development Council prepared and accepted a Development Strategy and a Complex Programme for the region. Since there was no decision about a separate programme till mid-2006, the council transformed the above mentioned documents into an allocation plan (detailed Balaton Plan 2006). In the end, the Balaton Region did not appear neither in a separate operational programme or a separate priority-axis in any OP. The decision-makers argued that the EU statistical nomenclature would not allow that. At that time, the preparation of the so-called Balaton Flagship Complex Programme was started, which did not have a separate resource frame. The financial background of its development was subdivided into sectoral and three regional OPs. The Ministry of Local Government and Regional Development was responsible for the coordination of the programme. However, in less than a year it turned out that the insti- 
tutional system was unable to handle the support construction that such a complex programme would require. As a consequence, the regional actors were forced to submit proposals for calls of different sectoral and regional programmes. The applicants from the Balaton region were more effective compared to the previous years, but the strategic objectives set out in the regional level plans were barely fulfilled.

With the coordination of the Balaton Development Council and with the professional assistance of the Lake Balaton Development Coordination Agency (a non-profit organization established in 2000 by the Council) planning documents for the Balaton area were also prepared for the 2014-2020 planning cycle. ${ }^{10}$ This time the documents were approved by the central government in November 2015 which also made a decision about the specified investments financed by EU or domestic funds in this period. EU aid of 280 billion forint was separated in 17 priority axis of 6 OPs. In July 2016, the government abolished its decision referring to the government restructuring of the tourism sector, but in December 2016 adopted a new revised version, amounting to 365 billion forint (264 billion forint worth of EU funds and 103 billion forint from national funds). The decision listed different objectives and particular projects and resources allocated to each item (an indicative financial allocation assigned to different OP constructions or national budgetary source). The Lake Balaton Development Coordination Agency has got the task of managing the application of development funds appropriated by the central budget based on the council's decisions. As a result of the strong and direct central government intervention, the development projects are making good progress.

\section{Conclusions}

The optimal territorial framework for regional policy interventions that takes account of synergies between different types of public intervention, integrate developments in the different sectors and which are likely to bring about impacts adapting to the spatial characteristics are defined by real economic and social structures. These functional regions cross administrative borders, often change in their territorial dimensions, and vary according to the different functions or different territorial levels. However, the framework for implementing development policy, as with any public policy, is heavily influenced by the administrative structure which is quite inflexible. This is a difficult-to-handle contradiction at both European and national level. Although, over the last decade both experts and EU regional policy documents have supported the idea that there is a need to think in terms of functional areas rather than areas within rigid administrative borders, the everyday practice have shown that this is not an easy task. Planning and management of the development programmes in functional regions would require territorially more flexible regulatory and institutional framework, vertical and horizontal coordination between decision-making bodies, and the involvement of local and regional actors.

The Hungarian case demonstrates that the overall impacts of EU cohesion policy on planning and development activities in functional regions have been controversial. Neither EU legislation and management nor implementation at member state level has made a significant contribution to integrated territorial developments of regions crossing administrative borders. The regulation of EU cohesion policy has always had features that have encouraged the member states to adapt their development system primarily to their administrative structure. The recent developments

\footnotetext{
${ }^{10}$ In the framework of the project called "Improving spatial planning activities in the Lake Balaton Resort Area 20142020", which was submitted by the Lake Balaton Development Council in the framework of the new Széchenyi Plan.
} 
have led to controversial effects in this respect. On the one hand the EU legislation has provided more tools for integrated developments in functional regions; on the other hand, the thematic concentration and tight performance control have strengthened less flexible, bureaucratic procedures. The principle of shared management has ensured a relatively large freedom for the member state governments in designing the territorial framework and institutional system of the implementation.

Since Hungary was not necessarily prepared for multi-level and geographically flexible territorial governance, the management of EU funds has mostly followed a centralized bureaucratic model. Regional development institutions based on the principle of partnership have got limited role in planning and implementation of EU programmes. Although functional regions have been always highlighted in national development documents, central government decisions have not consistently followed the lines set out in the spatial concepts. The complexity and the lack of management structures have set back the implementation of complex programmes even if originally designed. Because of the general centralization process from 2011, nowadays there are neither local nor territorial level authorities with sufficient powers, financial resources, or adequate management capacity, so there is no chance for bottom-up construction at functional region level. Challenges for managing territorial units which do not fit to administrative borders have even confirmed recentralization processes in Hungary. Since functional regions do not fit into the general implementation structure, the central government increasingly takes project-level decisions regarding the development in functional regions. In this situation, there is a high risk that local aspects and territorial coordination requirement would fade into the background.

\section{References}

Boldizsár A., Kékesi Z., Koroknai P., Sisak B., 2016. Review of Hungarian EU transfers - at the border of two fiscal periods. Financial and Economic Review, vol. 15, no. 2, pp. 59-87.

Brusis M., 2014. Paths and Constraints of Subnational Government Mobilization in East-Central Europe. Regional and Federal Studies, vol. 24, no. 3, pp. 301-319.

Dąbrowski M., 2013. EU cohesion policy, horizontal partnership and the patterns of sub-national governance: Insights from Central and Eastern Europe. European Urban and Regional Studies, vol. 21, no. 4, pp. 364-383.

Dąbrowski M., 2014. Towards place-based regional and local development strategies in Central and Eastern Europe? EU cohesion policy and strategic planning capacity at the sub-national level. Local Economy: The Journal of the Local Economy Policy, vol. 29, no. 4-5, pp. 378-393.

Falu-Város-Régió, 2016. Fókuszban a területi együttmüködések [Territorial Cooperation is in Focus], vol. 1.

Kabai G., 2012. The Possibilities Of Lake Balaton Resort Area in the System of the Development Policy 2006-2012. DETUROPE - The Central European Journal of Regional Development and Tourism, vol. 5 , no. 2, pp. 60-82.

Kabai G., 2016. Regionalizmus és területi politika a Balaton térségében [Regionalism and regional policy in the Balaton Region]. PhD Theses, Pécsi Tudományegyetem Bölcsészettudományi Kar Interdiszciplináris Doktori Iskola, Pécs.

Magyarország Partnerségi Megállapodása a 2014-2020-as fejlesztési időszakra [Partnership Agreement for Hungary, 2014-2020].

Mendez C., Batchler J., Wishlade F., 2011. Comparative study on the visions and options for cohesion policy after 2013. Brussels, European Parliament, http://www.europarl.europa.eu/studies [6 November 2018]. 
Mezei C., 2013. Case study report. Building Structural Fund management systems: Learning by doing or imitating? [in:] ESPON TANGO - Territorial Approaches for New Governance: Annex A: Case Studies. ESPON, Luxemburg, pp. 91-110, http://www.espon.eu/export/sites/default/Documents/ Projects/AppliedResearch/TANGO/ESPON_TANGO_Case_Study_Annex_A_final.pdf [6 November 2018].

Mezei C., 2016. Limited involvement: the role of local and regional actors in the Hungarian Structural Fund management. [in:] P. Schmitt, L. V. Well (ed.) Territorial Governance across Europe: Pathways, Practices and Prospects. London; New York: Routledge, pp. 157-170.

Pálné Kovács I. (ed.), 2016. A magyar decentralizáció kudarcának nyomában [In the wake of Hungarian decentralization failure]. Dialóg Campus Kiadó.

Pálné Kovács I., Mezei C., 2016. Regionális politikai és területi kormányzási ciklusok Közép- és Kelet-Európában [Cycles of regional policy and territorial governance in Central and Eastern Europe]. Tér és Társadalom, vol. 30, no. 4, pp. 54-69.

Perger É., 2010. Az EU kohéziós politika kormányzati irányításának magyar sajátosságai [Characteristics of the Management System for EU Cohesion Policy in Hungary]. Tér és Társadalom, vol. 24, no. 1, pp. 119-136, http://tet.rkk.hu/index.php/TeT/article/view/1299/2594_[6 November 2018].

Perger É., 2010. Az EU regionális támogatások hatása a területi decentralizáció folyamataira [The impact of EU Structural Policy on the processes of territorial decentralization]. Comitatus: Önkormányzati szemle, vol. 20, no. 1-2, pp. 3-20.

Perger É., 2016. Local Responses to the Structural Changes of National Development Policy in Hungarian Rural Regions. Eastern European Countryside, vol. 22, no. 1, pp. 69-83.

Perger É., Kovács A. D., Lennert J., 2014. Fejlesztési tapasztalatok vidéki térségekben [Development experiences in rural areas]. A FALU, vol. 29, no. 2, pp. 39-50.

Salamin G., 2018. A földrajzi tér alakításának európaizálódása [The Europeanization of the transformation of the geographical space]. PhD Theses, Szent István Egyetem, Gödöllő.

Stead D., Pálné Kovács I., 2016. Shifts in governance and government across Europe. [in:] P. Schmitt, L. V. Well (ed.) Territorial Governance across Europe: Pathways, Practices and Prospects. London; New York: Routledge, pp. 21-35.

Svensson S., Ocskay Gy. (eds.), 2016. Overview of the EGTCs around Hungary. Central European Service for Cross-Border Initiatives Budapest Observatory of Borders, Budapest.

The New Hungary Development Plan - National Strategic Reference Framework for Hungary 2007-2013.

XXI/1996. Act on Regional Development and Physical Planning, and its amendments in 1999, 2003, 2004, 2011, 2013, 2016.

35/1998. (III. 20.) Parliament Resolution on the National Spatial Development Concept.

97/2005. (XII. 25.) Parliament Resolution on the National Spatial Development Concept.

1/2014. (I. 3.) Parliament Resolution on National Development 2030 - National Development and Territorial Development Concept.

2012, B/31. Government Report to the Parliament on the developments of the country's territorial processes, the effects of the regional development policy and the implementation of the physical plans, the revision of the National Spatial Development Concept and the situation of the Hungarian settlement network.

2016, B/13058. Government Report to the Parliament on the evolution of the country's territorial processes between 2009 and 2014, the effects of the regional development policy, the implementation of the physical plans, the use of funds for spatial development and the international and cross-border development and spatial planning activities. 